\title{
Analisa dan Implementasi Sistem Informasi Pengeluaran Kas Kecil Pada PT. Bank Bukopin Berbasis Web
}

\author{
Yuni Eka Achyani ${ }^{1}$, Anggi Velayati ${ }^{2}$ \\ ${ }^{1}$ Sekolah Tinggi Manajemen Informatika dan Komputer Nusa Mandiri \\ e-mail: yuni.yea@nusamandiri.ac.id \\ ${ }^{2}$ Universitas Bina Sarana Informatika \\ e-mail: anggidks@gmail.com
}

\begin{abstract}
The application of a petty cash disbursement information system in a company is very important because by applying the petty cash disbursement information system, the company can supervise and control the course of the company's operational activities so that it can run as it should. This study aims to find out how the petty cash fund accounting system applied at PT. Bank Bukopin West Bekasi, is it in accordance with SOP (operational standards) in the company, and to find out the weaknesses of the system that is already running. From the results of this study obtained a discussion that in the petty cash expenditure PT. Bank Bukopin West Bekasi is still done manually starting from recording data to storing other data relating to the petty cash disbursement process to reporting. The research method used by the author is to use field research, interview methods and library methods while the software development method used by the writer is the waterfall method with the SDLC model. So according to the research of PT. Bank Bukopin West Bekasi requires a system that is expected to produce better reports in support of petty cash activities. The programming language used in development is to use a MySQL database and an editor using Notepad ++. This research will discuss about a web-based petty cash expenditure information system that is how the submission process, reimbursement, capital and reports. The author's purpose of this research is a small cash expenditure information system with the hope that it can overcome the obstacles that have occurred in the small cash expenditure system manually, and can assist in the process of making reports.
\end{abstract}

Keywords: information system, Cash Expenditures, website based, Waterfall

\section{PENDAHULUAN}

Teknologi dan informasi saat ini berkembang sangat pesat seiiring dengan kebutuhan manusia. Kelebihan yang didapat dari pengolahan data menggunakan sistem terkomputerisasi yaitu dapat mengolah data dengan cepat dan akurat (Damayanti \& Hernandez, 2018). Selain itu pengolahan data menggunakan sistem terkomputerisasi juga dapat mengolah data dalam kapasitas besar, dapat menyimpan arsip atau file dengan baik tanpa memerlukan tempat yang banyak. Saat ini perusahaan telah menggunakan sistem komputer untuk mencatat semua transaksi perusahaan sehingga data tersedia secara otomatis, lebih efektif dan efisien bagi perusahaan (Esteria \& dkk, 2016).

Perkembangan Sistem Informasi dan Teknologi informasi pada saat ini juga bagian yang tidak terpisahkan bagi dunia bisnis. Karena banyaknya fasilitas kemudahan yang ditimbulkan, Sehingga sistem informasi telah menjadi suatu kebutuhan yang mendesak di berbagai bidang kehidupan termasuk bidang bisnis. Sebagian besar organisasi bisnis telah menjadikan sistem informasi sebagai bagian yang penting bagi kelangsungan bisnisnya, namun sebagian lagi masih belum menggunakan sistem informasi secara optimal. Salah satu yang belum menggunakan sistem informasi secara optimal adalah PT. Bank
Bukopin Bekasi Barat dalam memproses keuangan kas kecil.

Didalam Dunia usaha, tentunya keuangan merupakan salah satu faktor yang penting dalam menunjang proses berjalannya suatu perusahaan. Dalam dunia akuntansi, juga dikenal dengan yang namanya kas, Kas merupakan pembayaran yang siap dan bebas digunakan perusahaan sewaktuwaktu apabila diperlukan. Karena dalam suatu perusahaan sering mengalami keluar masuknya kas untuk kebutuhan perusahaan, kas dibagi menjadi 2 yaitu kas bank (perusahaan yang disimpan di bank dalam bentuk simpanan) dan kas kecil (petty cash). Kas Kecil (Petty cash) adalah sejumlah dana yang dibentuk khusus untuk pengeluaran yang bersifat rutin dan relatif kecil jumlahnya yang tidak ekonomis bila dibayar dengan cek (Diana \& Setiawati, 2011).

Pada saat ini Bank Bukopin masih menggunakan sistem manual untuk melakukan pengelolaan pengeluaran kas kecil, salah satu kendala yang dirasakan dalam sistem manual ini adalah menjumlahkan total pengeluaran kas kecil di excel untuk membuat laporan dengan menjumlahkan total kas kecil harian, belum maksimalnya pencatatan keluaran masuknya data pengeluaran kas kecil, belum maksimalnya tahapan pembuatan laporan terkadang masih terjadi selisih dalam perhitungan. 
Oleh karena itu diperlukan sistem informasi yang baik dalam mengelola kas kecil, dengan demikian perusahaan dapat memperkirakan kebutuhan kas secara akurat. Pengelolaan pengeluaran kas kecil yang baik akan membawa perusahaan kepada tujuan yang ingin dicapai Sehingga untuk menghasilkan suatu pengelolaan yang baik, maka perlu disusun suatu sistem informasi akuntansi pengeluaran kas kecil yang dapat menghasilkan suatu informasi yang memadai guna meningkatkan pertanggung jawaban dan menghindari penyelewengan terhadap kas kecil, berdasarkan kendala-kendala yang tersebut diatas, penulis tertarik untuk melakukan penelitian yang dituangkan dalam analisa dan implementasi sistem informasi pengeluaran kas kecil berbasis web pada PT. Bank Bukopin.

Menurut Mulyadi "Pengeluaran kas dalam perusahaan dilakukan dengan dua sistem yakni sistem pengeluaran kas menggunakan cek dan sistem pengeluaran kas dengan uang tunai melalui sistem dana kas kecil. Pengeluaran kas yang tidak dapat dilakukan dengan cek (biasanya karena jumlah relatife kecil) (Mulyadi, 2016).

Penelitian ini tidak lepas dari teori-teori yang mendukung kemudahan dalam mempelajari, menganalisa serta implementasi daripada sistem infomasi yang diharapkan dapat berfungsi secara maksimal. Kemudahan dalam menggunakan sistem informasi bagi setiap pengguna akan sangat membantu dalam menyelesaikan setiap pekerjaan.

Keuntungan lain dari suatu sistem informasi yang digunakan adalah akan memperkecil kemungkinan terjadinya kesalahan yang dilakukan oleh pengguna pada saat menjalankan sistem informasi tersebut (Achyani \& Arviana, 2018). Berikut adalah teoriteori pendukung yang memperkuat penelitian ini.

1. Sistem

Sistem merupakan prosedur logis dan rasional guna melakukan atau merancang suatu rangkaian komponen yang berhubungan satu sama lain (L. James Havery) (Darmawan, 2013).

2. Informasi

Informasi adalah data-data yang telah diolah sehingga dapat berguna bagi siapa saja yang membutuhkan (Darmawan, 2013).

3. Sistem Informasi

Sistem informasi adalah suatu sistem didalam suatu organisasi yang mempertemukan kebutuhan pengolahan transaksi harian yang mendukung fungsi operasi organisasi yang bersifat manajerial dengan kegiatan strategi dari suatu organisasi untuk dapat menyediakan laporan-laporan yang diperlukan ileh pihak luar tertentu (Darmawan, 2013).

4. Kas Kecil

"Kas Kecil adalah kas yang diselisihkan entitas untuk membayar berbagai macam beban yang jumlah rupiah nya kecil, seperti ongkos taksi, pembelian perlengkapan kantor, atau makan siang karyawan", (Giri, 2017).

5. Bank

"Bank adalah lembaga bisnis yang unik yang tidak sama dengan lembaga-lembaga bisnis lainya, baik yang tidak sama dengan lembaga-lembaga bisnis lainya, baik bisnis di sector keuangan maupun bisnis di sektor riil" (Joyosumarto, 2018).

6. Website

"Website atau situs dapat diartikan sebagai kumpulan halaman-halaman yang digunakan untuk menampilkan informasi teks, gambar diam atau gerak, animasi, suara, video dan atau gabungan dari semuanya, baik yang bersifat statis maupun dinamis yang membentuk satu rangkaian bangunan yang saling terkait, yang masing-masing dihubungkan dengan jaringanjaringan halaman” (Hidayat, 2010).

7. MySQL

"MySQL adalah sebuah database". Database merupakan sebuah tempat untuk menyimpan data yang jenisnya beraneka ragam. MySQL merupakan tipe data relasional yang artinya MySQL menyimpan datanya dalam bentuk tabeltabel yang saling berhubungan" (Winarno, Zaky, \& Community, 2014).

\section{METODOLOGI PENELITIAN}

Dalam penelitian sistem informasi pengeluaran kas kecil berbasis web pada PT. Bank Bukopin ini metode pengumpulan data yang digunakan adalah metode riset lapangan, wawancara dan studi pustaka. Sedangkan pengembangan sistem perangkat lunak yang penulis gunakan menggunakan model waterfall. "Model Waterfall adalah sebuah proses hidup perangkat lunak yang memiliki sebuah proses yang linear dan sekuensial" (Sukamto \& Salahudin, 2016).

Tahapan - tahapan yang ada pada model waterfall secara umum (Sukamto \& Salahudin, 2016) adalah:

a. Analisis Kebutuhan

"Adalah proses pengumpulan kebutuhan yang dilakukan secara intensif untuk mespesifikasikan kebutuhan perangkat lunak agar dapat dipahami sepertiapa yang dibutuhkan oleh user".

b. Desain

"Adalah proses multi langkah yang fokus pada desain pembuatan program perangkat lunak termasuk strutur data, arsitektur perangkat lunak, representasi antar muka dan prosedur pengkodean".

c. Pembuatan Kode Program 
“Adalah desain harus ditranslasikan ke dalam program perangkat lunak.

d. Pengujian

"Adalah fokus pada perangkat lunak secara dari segi lojik dan fungsional dan memastikan bahwa semua bagian sudah diuji”. Hal ini dilakukan untuk meminimalisir kesalahan dan memastikan keluaran yang dihasilkan sesuai dengan yang diinginkan.

e. Pendukung atau Pemeliharaan

"Adalah tahapan yang dapat mengulangi proses pengembangan mulai dari analisis spesifikasi untuk perubahan perangkat lunak yang sudah ada, tapi tidak untuk membuat perangkat lunak baru".

\section{HASIL DAN PEMBAHASAN}

Bank bukopin mulai melakukan usaha komersial sebagai bank umum koperasi di Indonesia sejak tanggal 16 maret 1971. Kantor pusat BBKP beralamat di gedung Bank Bukopin, Jalan M.T. Haryono kav. 50-51, jakarta 12770 - Indonesia. Saat ini Bank Bukopin memiliki 41 kantor cabang pembantu, 75 kantor fungsional, 152 kantor kas dan payment points.

Perseroan juga memiliki anak perusahaan yaitu, PT. Bank Syariah Bukopin Finance, dengan hasil usaha yang dikonsolidasikan kedalam Laporan Keuangan Bank Bukopin dan PT. Bukopin Finance PT. Indo Trans Buana Multi Finance didirikan pada tanggal 11 Maret 1983, merupakan perusahaan yang bergerak dibidang pembiayaan sewa guna usaha dan multifinance Sedangkan Bank Syariah Bukopin (PT. Bank Persyarikatan Indonesia), didirikan pada tanggal 11 September 1990 yang bergerak di bidang perbankan berbasis syariah.

Sistem Pengeluaran kas kecil pada PT. Bank Bukopin Bekasi saat ini masih menggunakan sistem yang kurang efisien dan efektif, sehingga terkadang terjadi kesalahan-kesalahan yang tidak diinginkan dan tidak disengaja (human error). Keamanan dokumen yang kurang terjamin dan tidak aman sehingga mudah hilang atau lupa dalam menyimpan dokumen tersebut, dan pembuatan laporan yang kurang akurat karena masih menghitung dan membuat laporan secara manual yang dapat menimbulkan kesalahankesalahan yang tidak diinginkan.

Maka dari itu penulis ingin membuatkan program berbasis web yang dapat memudahkan dalam penginputan data, penyimpanan data sampai ke pembuatan laporan pengeluaran kas kecil.

\section{Proses Bisnis Sistem Berjalan}

Berikut adalah Activity diagram sistem pengeluaran kas kecil pada PT. Bank Bukopin Bekasi: a. Activity diagram reimburse

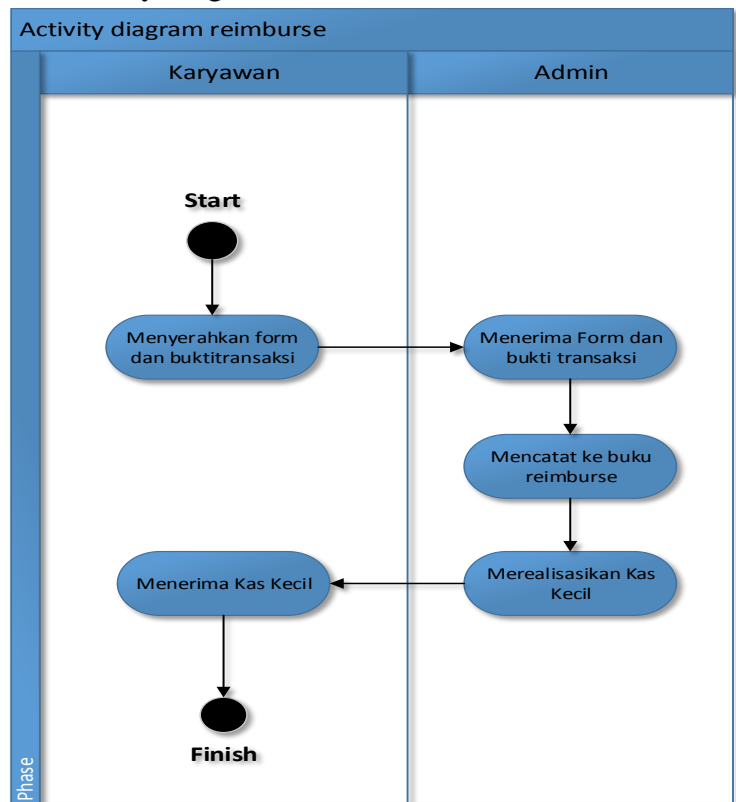

Sumber: (Achyani \& Velayati, 2018)

Gambar 1. Activity diagram reimburse

b. Activity diagram Pengajuan

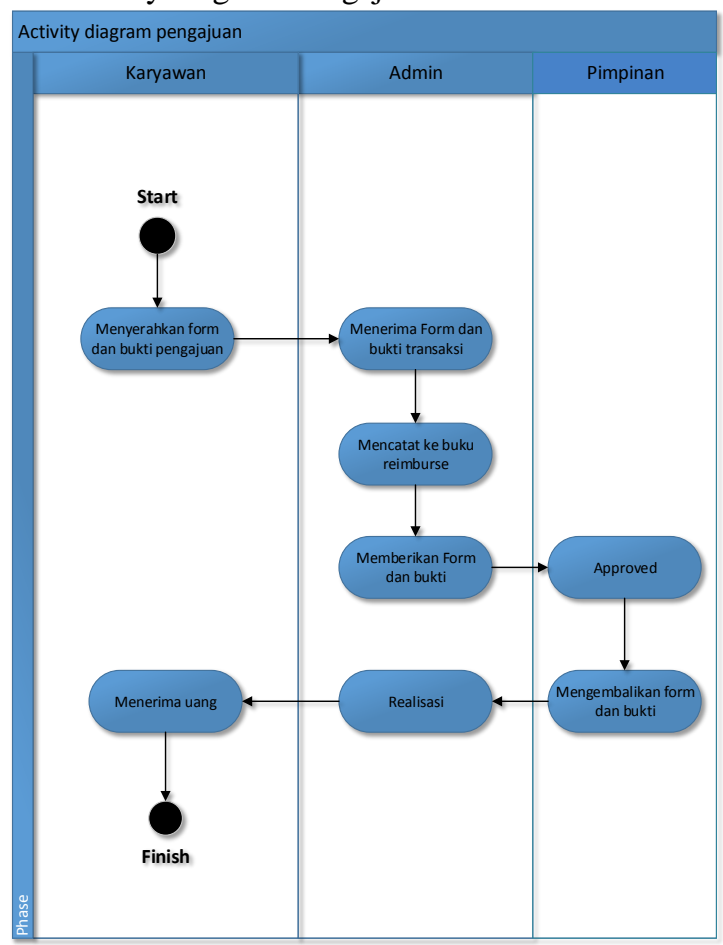

Sumber: (Achyani \& Velayati, 2018)

Gambar 2. Activity diagram pengajuan

c. Activity diagram permintaan modal 


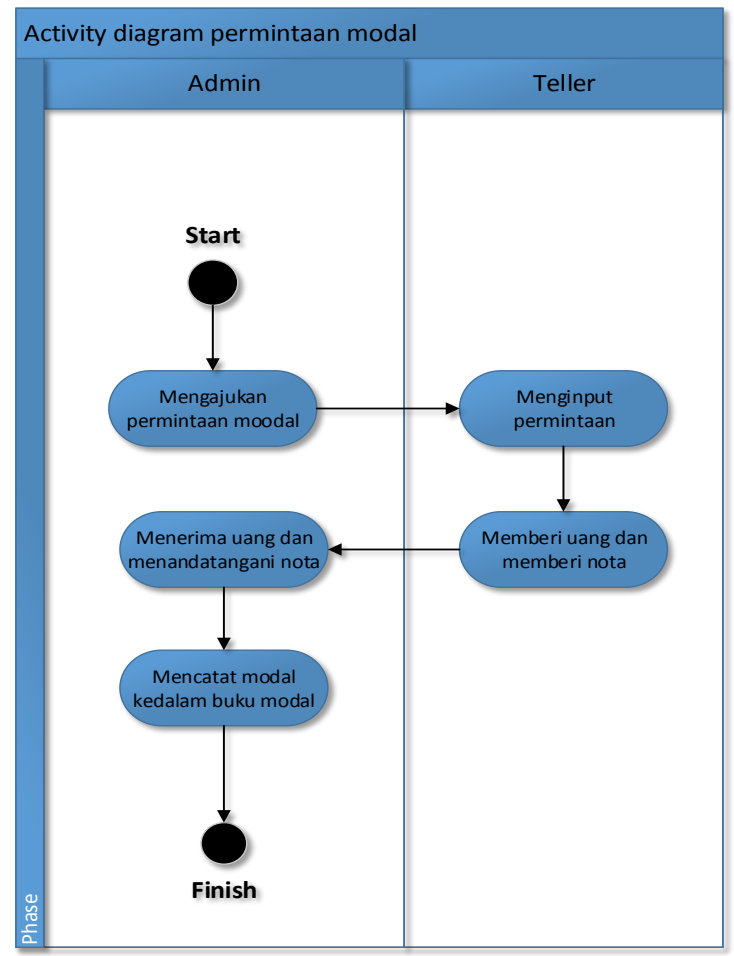

Sumber: (Achyani \& Velayati, 2018)

Gambar 3. Activity diagram permintaan modal

d. Activity diagram laporan

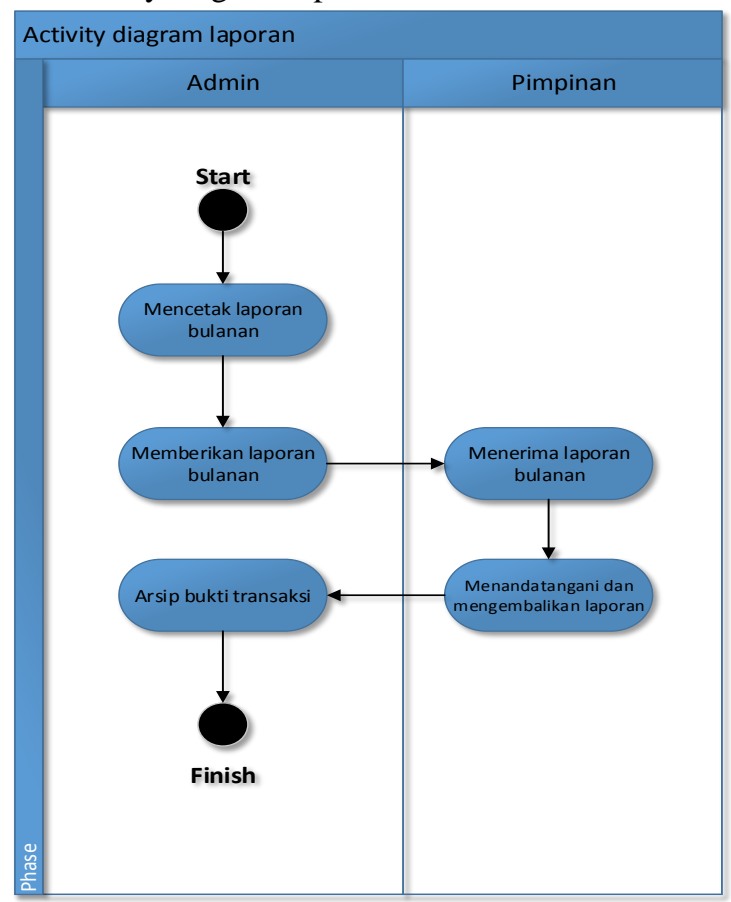

Sumber: (Achyani \& Velayati, 2018)

Gambar 4. Activity diagram laporan

\section{Analisa Kebutuhan Software}

\section{a. Tahapan Analisis}

Berdasarkan proses pengeluaran kas kecil pada Bank Bukopin Bekasi, maka tahapan analisis kebutuhan dari sistem pengeluaran kas kecil adalah sebagai berikut:
A. Admin :

A.1. Melakukan Login Sistem

A.2. Mengelola Data Pengajuan

A.3. Mengolala Data Reimburse

A.4. Mengelola Modal

A.5. Mencetak Laporan

A.6. Mengelola Data Perkiraan

A.7. Logout

B. Pimpinan

B.1. Melakukan Login Sistem

B.2. Approved pengajuan

A.3. Logout

b. Use Case Diagram

1) Use Case Diagram Halaman Admin

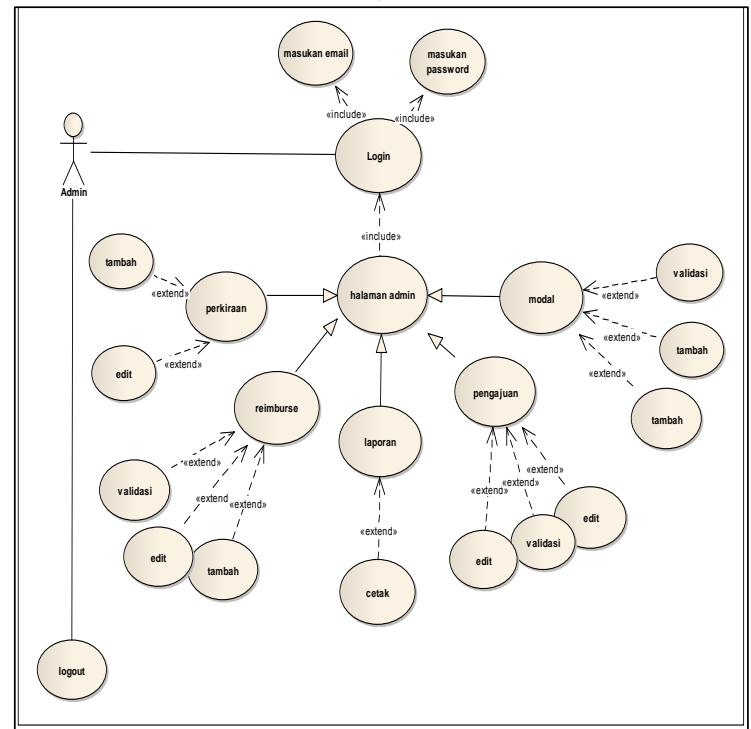

Sumber: (Achyani \& Velayati, 2018)

Gambar 5. Use Case Diagram Halaman Admin

2) Use Case Diagram Halaman Pimpinan

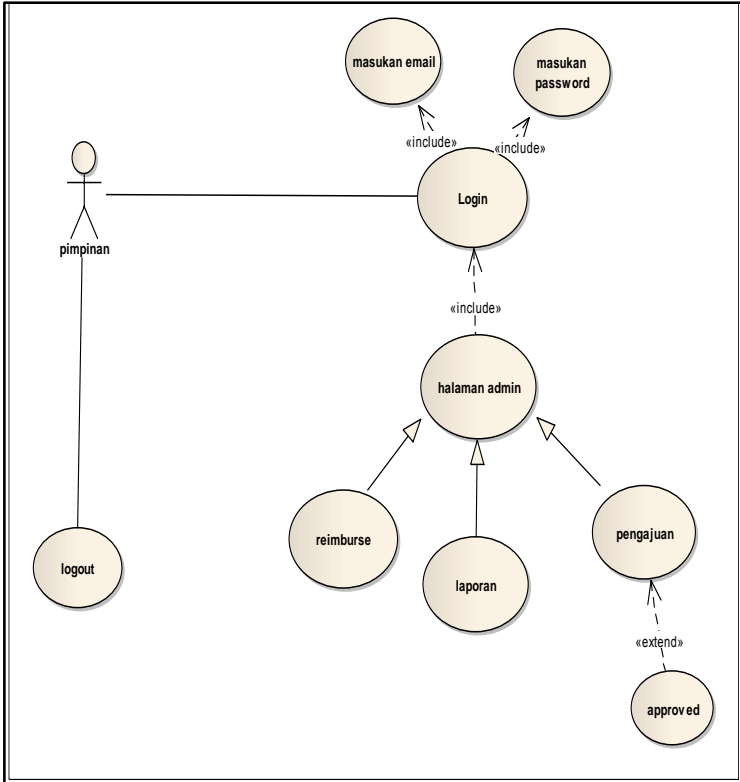

Sumber: (Achyani \& Velayati, 2018)

Gambar 6. Use Case Diagram Halaman Pimpinan

c. Entity Relationship Diagram (ERD) 


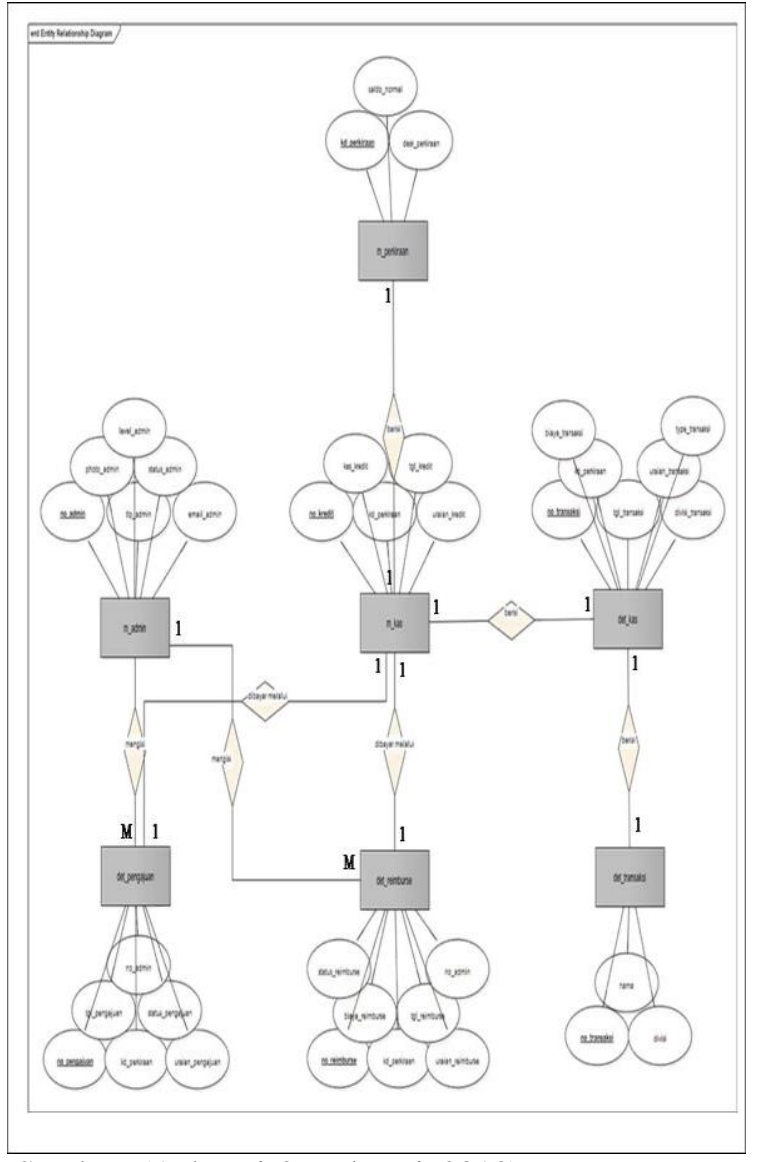

Sumber: (Achyani \& Velayati, 2018)

Gambar 7. Entity Relationship Diagram (ERD)

\section{d. Logical Record Structure (LRS)}

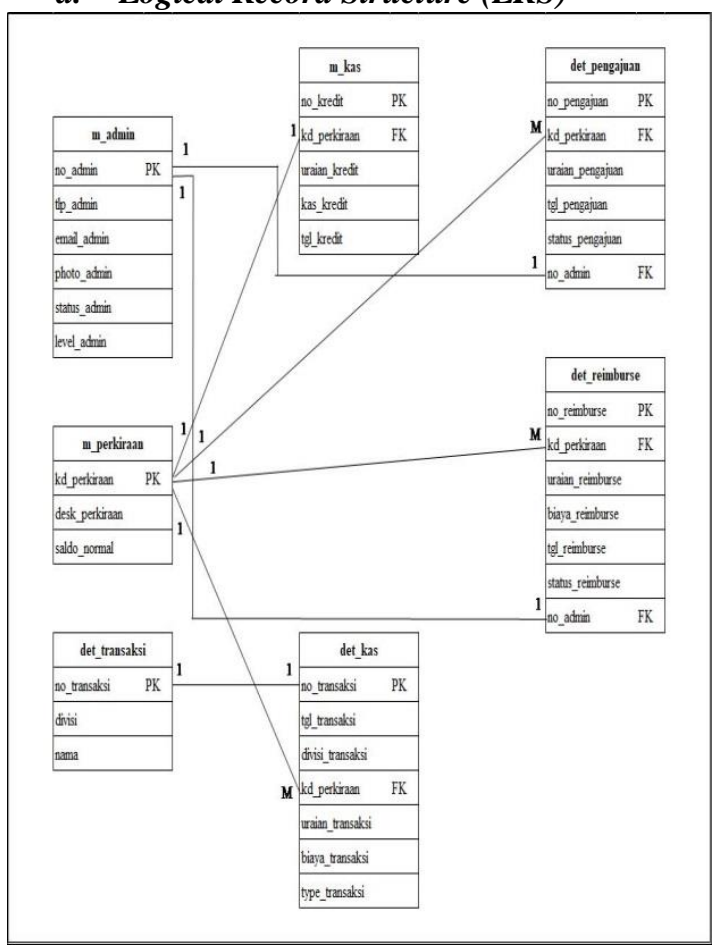

Sumber: (Achyani \& Velayati, 2018)

Gambar 8. Logical Record Structure (LRS)

\section{Desain User Interface}

Rancangan form masukan yang disediakan disesuaikan dengan kebutuhan, sesuai dengan dokumen masukan yang ada pada PT. Bank Bukopin Bekasi. Untuk menjaga keamanan data, maka peneliti merancang form login, yang berfungsi untuk membatasi siapa saja yang berhak untuk melakukan pengolahan data pengeluaran kas kecil dan membatasi hak akses user.

Berikut merupakan tampilan user interface Sistem Informasi Pengeluaran Kas Kecil pada PT. Bank Bukopin Bekasi:

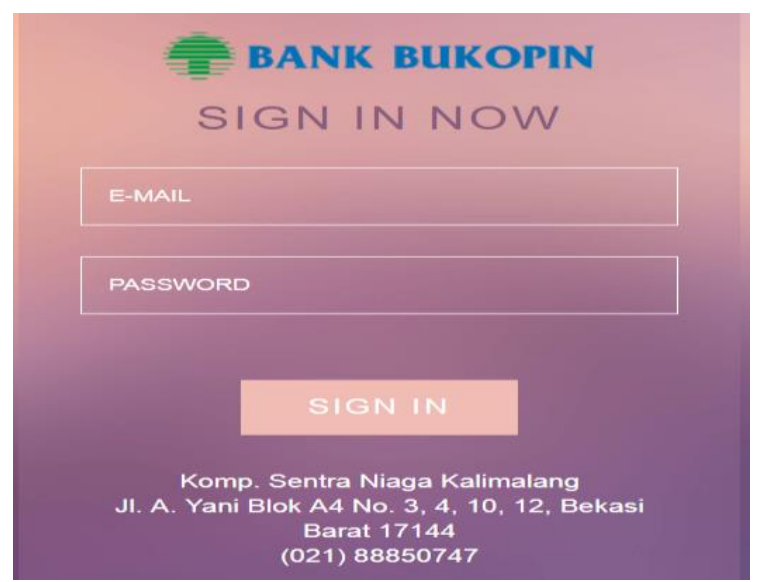

Sumber: (Achyani \& Velayati, 2018)

Gambar 9. User Interface Form Login

Pada desain Menu Login terdapat kolom untuk mengisi E-mail dan password pengguna. Dimana Email tersebut memakai email pengguna dan password mengunakan nomor induk pegawai.

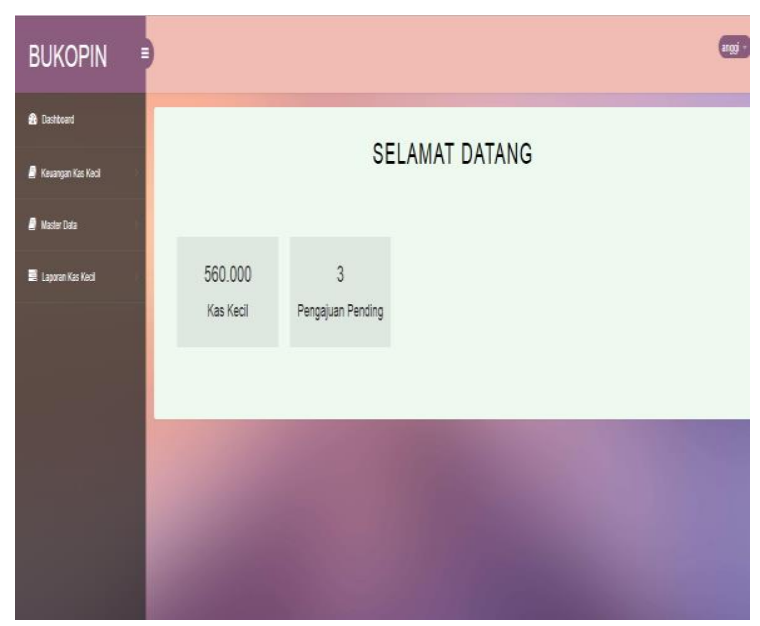

Sumber: (Achyani \& Velayati, 2018)

Gambar 10. User Interface Menu Utama

Pada desain Menu Utama Sistem Informasi Pengeluaran Kas Kecil di PT. Bank Bukopin Bekasi. ini terdapat Menu Keuangan Kas Kecil, Master Data, Laporan Kas Kecil dan juga terdapat sisa saldo kas kecil, data pengajuan yang masih pending yaitu yang belum di acc oleh Manager Operasional. 
Selanjutnya, desain Menu Profile. Pada desain Menu User terdapat data Pengguna terdapat kolom untuk mengisi username, Nama Lengkap dan sandi. Juga ada tombol pilihan, batal, simpan.

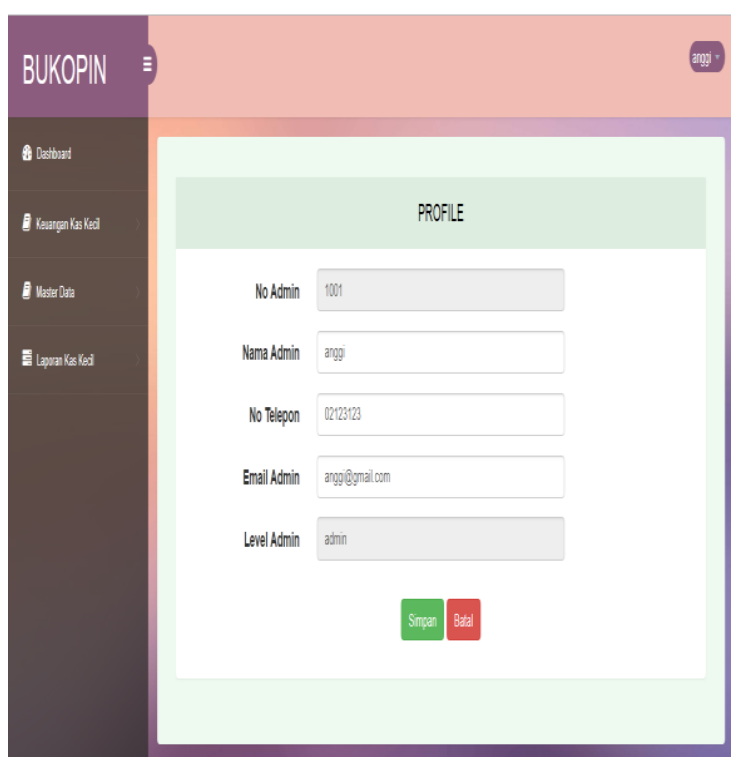

Sumber: (Achyani \& Velayati, 2018)

Gambar 11. User Interface Menu Profile

Berikutnya, menu Keuangan Kas Kecil terdapat menu Pengajuan digunakan bagi kayawan yag ingin mengajukan dana untuk membeli keperluan kantor akan tetapi struk diberi di akhir setelah pembelian diselesaikan. pada halaman pengajuan terdapat menu tambah pengajuan,divisi, nama karyawan, kode, uraian, nominal, batal, simpan.

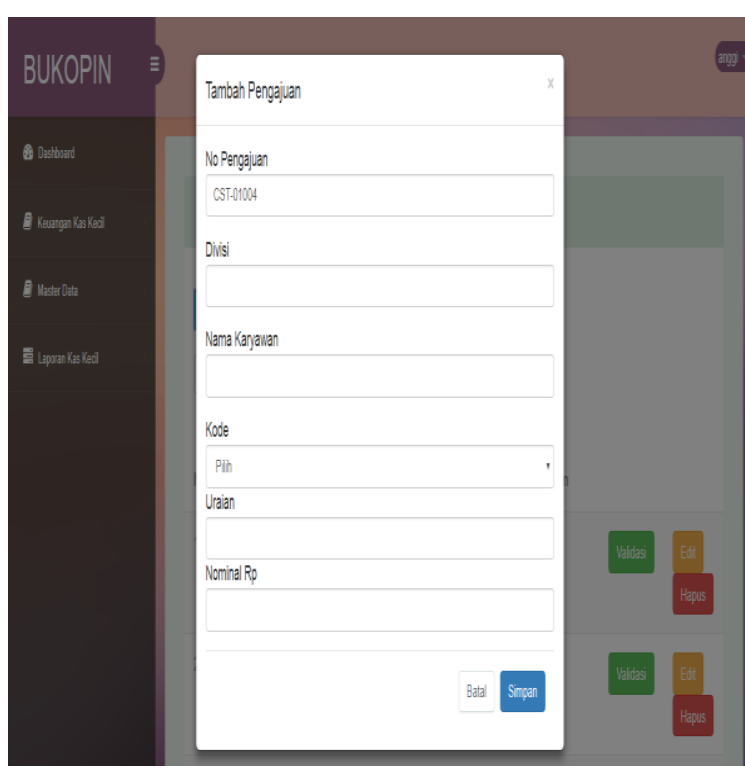

Sumber: (Achyani \& Velayati, 2018)

Gambar 12. User Interface Menu Pengajuan

Menu Keuangan Kas Kecil terdapat menu Reimburse digunakan untuk keperluan kantor yang digunakan rutin setiap harinya, pada halaman pengajuan terdapat menu tambah pengajuan, no.reimburse, divisi, nama karyawan, kode, uraian, nominal, batal, simpan.

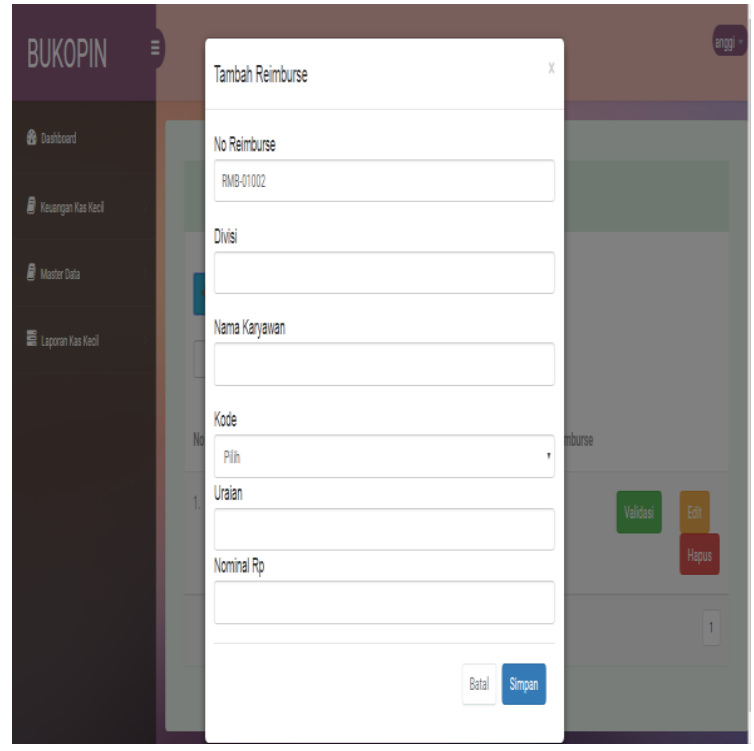

Sumber: (Achyani \& Velayati, 2018)

Gambar 13. User Interface Menu Reimburse

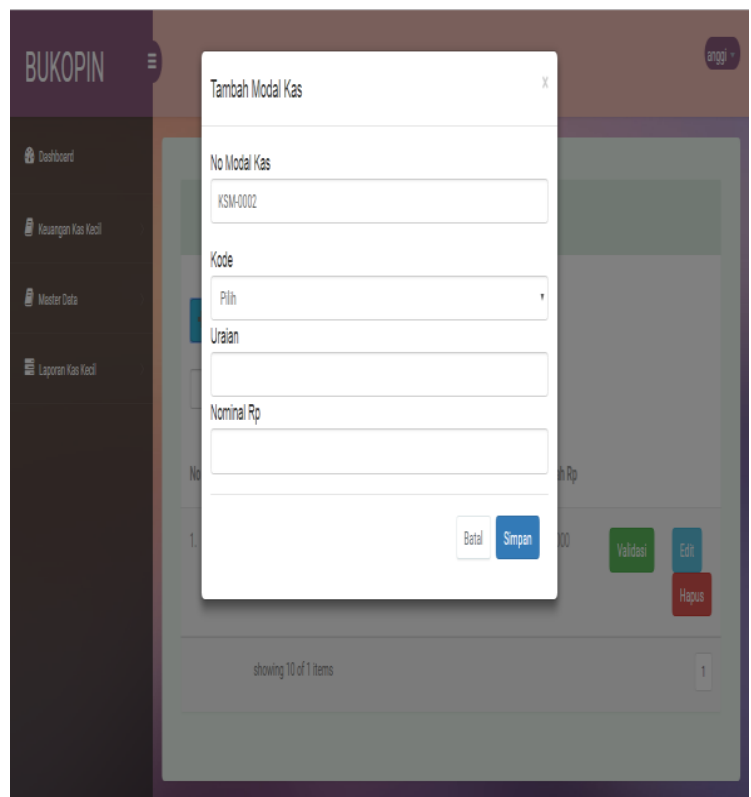

Sumber: (Achyani \& Velayati, 2018)

Gambar 14. User Interface Menu Modal

Dan terakhir adalah menu Laporan Transaksi Bulanan. Desain laporan memiliki menu cetak,detail, pencariann tanggal dengan no. Transaksi. 


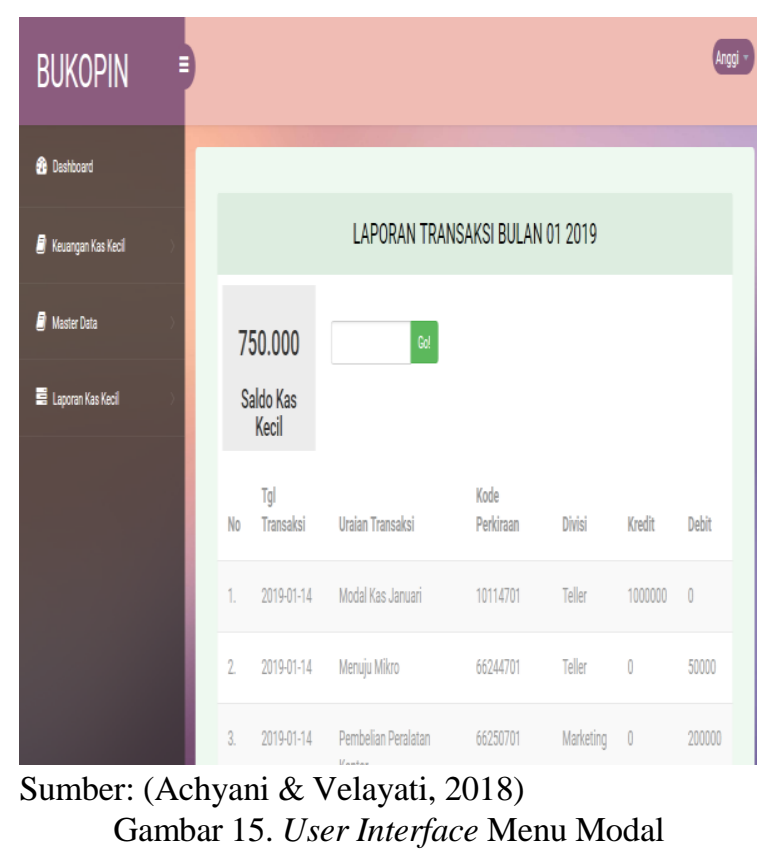

\section{KESIMPULAN}

Dari hasil penelitian tentang sistem informasi pengeluaran kas kecil pada PT. Bank Bukopin Bekasi, maka penulis mengambil kesimpulan yakni: Peningkatan pengendalian internal pada sistem informasi pengeluaran kas kecil dengan merubah sistem manual menjadi komputerisasi dengan merancang sistem informasi berbasis web sehingga proses pencatatan transaksi lebih dapat dipertanggungjawabkan.Untuk mempermudah Staff Sarlog dan manager operasional dalam mengelola data pengeluaran kas kecil. Mempermudah dalam proses pencatatan pengeluaran kas kecil. Serta mempermudah pembuatan seluruh laporan pengeluaran kas kecil yang dapat dibuat secara otomatis.

Dari pembahasan diatas, penulis mencoba memberikan beberapa saran sebagai alternatif pemikiran dengan harapan agar lebih dapat meningkatkan kualitas dalam penggunaan dan pengembangan program ini. Adapun saran-saran tersebut adalah :

1. Pelatihan dalam menggunakan Aplikasi pengeluran kas kecil ini untuk mempermudah dalam menggunakan program ini, baik pelatihan sebagai admin maupun user.

2. Perlu dilakukan backup data secara berkala untuk mencegah terjadinya kehilangan data atau kerusakan program baik akibat kelalaian manusia, mesin, atau bencana alam.

3. Dalam aplikasi pengeluaran kas kecil ini belum sempurna dan belum bisa melakukan penyuratan sanksi, oleh karenanya penulis berharap jika ada yang ingin melanjutkan proses riset tentang program ini, supaya dilengkapi untuk berbagai jenis penyuratan sanksi.

\section{REFERENSI}

Achyani, Y. E.;\& Arviana, E. (Februari 2018). Sistem Informasi Pendapatan Jasa Pada Koperasi PDAM Tirta Patriot Bekasi. Jurnal Teknik Komputer, 4, 178-185.

Damayanti, D., \& Hernandez, M. Y. (2018). SISTEM INFORMASI AKUNTANSI PENERIMAAN DAN PENGELUARAN KAS PADA KPRI ANDAN JEJAMA KABUPATEN PESAWARAN. Tekno Kompak, 12, 57-61.

Diana, A., \& Setiawati, L. (2011). Sistem Informasi Akuntansi. Yogyakarta: CV. Andi Offset.

Darmawan, D. (2013). Sistem Informasi Manajemen. Bandung: Remaja Rosdakarya.

Esteria, N. W., \& dkk. (2016). Analisis Sistem Akuntansi Penerimaan dan Pengeluaran Kas Pada PT Hasjrat Abadi Manado. Berkala Ilmiah Efisiensi, 16, 1087-1097.

Giri, E. (2017). Akuntansi Keuangan Menengah. Yogyakarta: UPP STIM YKPN.

Hidayat, R. (2010). Cara Praktis Membangun Website Gratis. Jakarta: Elex Media Komputindo.

Hidayatulloh, P. D. (2014). Pemrograman Web. Bandung: Informatika Bandung.

Joyosumarto, S. (2018). Kepemimpinan Lembaga Perbankan Abad Ke-21. Jakarta: PT. Elex Media Komputindo.

Mulyadi. (2016). Sistem Akuntansi Edisi Keempat. Jakarta: Salemba Empat.

Sukamto, R. A.;\& Salahudin, M. (2016). Rekayasa Perangkat Lunak Terstruktur dan Berorientasi Objek. Bandung: Informatika.

Winarno, E.;Zaky, A.;\& Community, S. (2014). 24 Jam Belajar PHP. Jakarta: Elex Media Komputindo.

\section{PROFIL PENULIS}

Yuni Eka Achyani, M.Kom. Tahun 2014 lulus dari Program Strata Satu (S1) Program Studi Sistem Informasi Sekolah Tinggi Manajemen Informatika dan Komputer Nusa Mandiri Nusa Mandiri dan Tahun 2016 lulus dari Program Magister (S2) Sekolah Tinggi Manajemen Informatika dan Komputer Nusa Mandiri. Saat ini bekerja sebagai Staff Pengajar (Dosen) di Sekolah Tinggi Manajemen Informatika dan Komputer Nusa Mandiri.

Anggi Velayati, A.Md. Tahun 2018 lulus dari program Ahli Madya (D3) Program Studi Sistem 
Paradigma - Jurnal Informatika dan Komputer,

Vol. 22 No 1, Maret 2020

P-ISSN 1410-5063, E-ISSN: 2579-3500

Informasi Akuntansi pada Universitas Bina Sarana Informatika. Sejak 2018 sampai saat ini

pada PT. Bank Bukopin.

bekerja sebagai Staf Pelayanan Nasabah (Teller) 